\title{
Three-dimensional geometry and interference of fault-bend folds: examples from the Ponga Unit, Variscan Belt, NW Spain.
}

\author{
J. ALVAREZ-MARRON \\ Departamento de Geología, Universidad de Oviedo, c/ Arias de Velasco s/n, \\ 33005 Oviedo, Spain.
}

\begin{abstract}
Examples of the three-dimensional geometry and interference patterns between fault-bend folds occur in the Ponga Unit of the Variscan Cantabrian foreland thrust and fold belt of northwestern Spain. The Ponga Unit consists of several east-directed thrust sheets with a cumulative displacement of $93 \mathrm{~km}$, which were emplaced during Upper Westphalian-Stephanian time. Two major lateral ramps developed in the basal thrust of the Ponga Unit, reaching 15 and $20 \mathrm{~km}$ in length, respectively, and some $3 \mathrm{~km}$ in height. Lateral structures are also common within the hangingwall thrust sheets.

The three-dimensional staircase trajectories of thrust faults, together with the tectonic superposition of thrust sheets, has produced a complex interference pattern of fault-related folds. Most map-scale folds formed as fault-bend folds related to interference between frontal and lateral ramps. Fold geometry and size varies depending on the geometry and size of the associated thrust ramp and flat. The axial traces are grouped into lateral and frontal sets, which are sub-parallel or sub-perpendicular to the tectonic transport direction, respectively. 'Corner folds' form with plunging axes at the intersections of frontal and lateral ramps and generally link pairs of frontal-lateral folds. They have relatively short axial traces that are oblique to the tectonic transport direction.

Fold plunge varies due to the superposition of lateral and frontal structures of a thrust fault and also depends on the geometry of subsequent thrusts in the footwall. The final geometry of frontal folds in the Ponga Unit are not only the result of the bending mechanism but have been modified by simple shear parallel to the emplacement direction. Major lateral structures have been reactivated as reverse faults and are locally overturned due to post-emplacement north-south compression.
\end{abstract}




\section{INTRODUCTION}

The genetic links between thrusts and folds in foreland thrust and fold belts have been recognized from geological and geophysical data since Rich (1934) first described them from the Appalachian Plateau. Since then the understanding of the structure in overthrust terranes has been based on the concept of foldthrust interactions (e.g. Suppe 1985, Jamison 1987). Several mechanisms have been proposed for the formation of thrust related folds (including Berger \& Johnson 1980, Suppe 1983, Ramsay et al. 1983, Coward \& Potts 1985).

A particular case of fault related folding is that of passive accommodation of hangingwall stratigraphy to the staircase trajectory of thrust faults. These have been described as fault-bend folds by Suppe (1979) who established their basic geometric parameters such as the relationships between inter-limb angle and fault dip (Suppe 1983). The recognition of fault-bend fold geometry has become a basic tool for the construction of balanced cross-sections and for determining the structure of thrust belts at depth (Suppe \& Chang 1983, Suppe et al. 1992). Furthermore, the fault-bend fold method has also been applied to the determination of the kinematic evolution of thrust systems (Geiser 1988). However, the geometrical analysis of fault-bend folds has been generally done in two dimensions and mainly for frontal structures. With the exception of lateral terminations of duplexes and culminations (i.e., Elliot \& Johnson 1980, McClay \& Coward 1981, Butler 1982a), descriptions of lateral structures are less frequent. More recently, the three dimensional geometry of fault-bend folds has been analyzed using computer generated models (Wilkerson et al. 1991, Apotria et al. 1992). Some field examples of fold interference have been analyzed by Stauffer (1988) and Stewart (1993).

The aim of this work is to describe the three-dimensional geometry of fault-bend folds using natural examples from the Ponga Unit of the Cantabrian Zone foreland thrust and fold belt (CZ), northwestern Spain (Fig. 1). The superposition of structures, formed as a consequence of different shortening directions in the $\mathrm{CZ}$, provides local views of the deep structure directly on the map, and makes this area exceptional for analyzing three-dimensional geometry and interference of foreland thrust belt structures.

Three- dimensional geometrical analysis of the structure of the Ponga Unit is based on the construction of balanced cross-sections and cut-off line maps as described by Mitra (1988). A classification of folds related to differently oriented ramps is proposed here. This allows a better understanding of the crossfolding pattern in the region. Constraints on the deep structure of the Ponga Unit are provided by erosional windows into the cores of well-developed lateral folds. 


\section{GEOLOGY OF THE CANTABRIAN ZONE}

The Cantabrian Zone (CZ) constitutes the arcuate foreland thrust and fold belt of the Variscan belt in the northwestern Iberian Peninsula (Fig. 1). The arcuate pattern in the $\mathrm{CZ}$ is defined by the major thrust units and is interpreted to have been partially formed during the convergent motion of the thrusts (Perez-Estaun et al. 1988). Within this zone a well-developed Paleozoic succession has been deformed by a large number of thrusts and folds. The Cambrian to Upper Devonian wedge-shaped preorogenic sedimentary package thins from $4500 \mathrm{~m}$ in the west to $200 \mathrm{~m}$ in the east beneath a low angle unconformity of Famenian age. Most of this sedimentary package contains platform facies sediments deposited on the margin of Gondwana, the Precambrian continent that was located to the east. The synorogenic sediments, which reach thicknesses of ca. $6000 \mathrm{~m}$ (Aller 1986), consist mainly of deltaic facies siliciclastic wedges of Carboniferous age. The clastic wedges were deposited during the east-directed thrusting, thus providing a constraint on the sequence of thrusting (Marcos \& Pulgar 1982).

Deformation in the $\mathrm{CZ}$ took place under shallow crustal conditions, resulting in a typical thinskinned deformation style with a basal detachment near the basement-cover contact (Julivert 1971, PerezEstaun et al. 1988). This thin-skinned style of deformation has been recently proved by deep seismic profiling (Perez-Estaun et al. 1994). The general sequence of thrusting was forward breaking towards the foreland with directions of emplacement changing in a clockwise manner from northeast-verging to south-verging, (PerezEstaun et al. 1988). Major folds have been divided into two sets: a set with axial traces trending sub-parallel to the outcrop trace of the thrust faults, and a second set with axial traces trending sub-perpendicular to the thrust faults (Julivert \& Marcos 1973). Recent studies have classified most folds of the first set as frontal thrust related folds (Alonso 1987, Perez-Estaun et al. 1988). Some folds of the second set have been classified as lateral thrust related folds (Alonso 1987, Bastida \& Castro 1988, Alvarez-Marron \& PerezEstaun 1988).

The Mesozoic-Tertiary evolution of the northern margin of the Iberian plate with extension and subsequent inversion has modified the previous Variscan structure of the CZ. The latest Alpine deformation consisted mainly of tangential movement along a gentle northward dipping, major reverse fault located at the southern edge of the $\mathrm{CZ}$ (Alonso et al. in press). Within the fault-bounded blocks of the hangingwall the Variscan structure has been preserved and can be recognized. The Alpine uplift resulted in the exposure of deeper levels of the Variscan structures.

\section{GEOLOGY OF THE PONGA REGION}

The frontal-most thrust unit in the core of the arc in the CZ is the Ponga Unit (Fig. 1, Julivert 1960, Alvarez-Marron 1989). A large stratigraphic gap spanning Lower Ordovician to Upper Devonian exists in the Ponga Unit (Fig. 2) due to its frontal position in the CZ. The pretectonic package contains 800 to $200 \mathrm{~m}$ thick Cambro-Ordovician rocks (Zamarreño \& Julivert 1967). Younger syntectonic rocks of Upper Devonian to Myachkovskian age constitute most of the stratigraphic sequence (Truyols \& Sanchez 1983). These rocks are up to $4000 \mathrm{~m}$ thick and include mainly shallow marine deltaic clastic and carbonate rocks (Villa \& Heredia 
1988). There are small patches of Stephanian rocks which unconformably overlie this series. These Stephanian rocks are also folded (see below) (Julivert 1960).

The Ponga Unit contains a large number of mainly east-directed thrust sheets which have sinuous map traces (Fig. 3a and b). The thrust sheets were emplaced in a foreland propagation sequence during the Upper Westphalian to Stephanian. Most thrust units exhibit large tectonic superposition with a cumulative amount of displacement of approximately $93 \mathrm{~km}$, corresponding to a shortening of $65 \%$ (Alvarez-Marron 1989). The number of thrust sheets varies along strike due to the existence of east-west trending lateral structures (Fig. 3b). As a consequence of the emplacement of the thrust systems from west to east, a large number of fault related folds formed.

Following the main phase of east-directed deformation and thrust sheet emplacement a north-south compressional deformation ensued. This later deformation resulted in the reactivation of earlier east-west trending structures and amplification of folds (Alvarez-Marron \& Perez-Estaun 1988) and may, in part, correspond to the along-strike effect of deformation related to the emplacement of the Picos de Europa Unit towards the south during Stephanian times (Perez-Estaun et al. 1988). Similar reactivation of structures may have occurred during the Alpine deformation of the northern Iberian margin. However, the lack of an Alpine sedimentary record in this area, makes it difficult to estimate the amount of shortening produced by each of the north-south compressional events. The total shortening obtained from a north-south section is more important in the eastern part of the Ponga Unit where it reaches $23 \%$ (Alvarez-Marron 1989).

Whatever the age of the deformation, it produced a change in the angular relationships between previously formed structural elements. For instance, the angle between frontal and lateral structures, being always less than $90^{\circ}$ throughout the Ponga area, decreases progressively towards the south where discrimination between lateral and frontal structures is more difficult.

\section{CROSS-SECTION CONSTRUCTION AND ARCHITECTURE OF THE THRUST SYSTEMS}

In an area with superimposed deformations such as the Ponga Unit, the first problem encountered in its structural analysis is to determine the orientation of plane strain sections suitable for balanced crosssection construction. The discrimination between lateral and frontal structures in the Ponga Unit, as well as in the $\mathrm{CZ}$, is obscured by three main factors. These are: 1) the arcuate geometry of the orogenic belt , 2) the change in the direction of thrusting (Perez-Estaun et al. 1988) and, 3) the existence of a later north-south compression that has changed the angular relationships between lateral and frontal structures (Alonso 1987). A detailed geometrical analysis of the thrust surfaces together with the analysis of the kinematic indicators of thrusts are necessary in order to determine accurately the position of lateral and frontal structures. As a result of post emplacement reorientation of structures, the constraints on the deep structure of the Ponga Unit are provided by erosional windows into the cores of well-developed lateral folds.

Three-dimensional structural analysis involved the construction of geological cross-sections in a grid with several section orientations (Fig. 3b). Corrections for the non-coincident directions of the section and the tectonic transport (Cooper 1983) were included during the balancing process. The whole set of cross-sections were balanced together using mainly the bed-length method, this provided a volume that would restore in 
three dimensions. The north-south compression was first eliminated by restoring east-west trending fault displacements. The compatibility of the sections in different directions was aided by the construction of cutoff and branch line maps for individual thrust faults. The constraints on the deep structure and the location of cut-off lines are provided by the cut-off points directly observed on the map (Fig. 3a).

Six representative balanced cross-sections of the Ponga Unit are shown in Figs. 4 and 5. The sections in Fig. 4 are sub-parallel to the emplacement directions and therefore show the frontal geometry of the thrust sheets. The Cantabrian Zone detachment is interpreted to be located below the Ponga Unit at an approximate depth of $6 \mathrm{~km}$ with a gentle dip towards the west. The oblique sections shown in Fig. 5 show the lateral relationships between thrust sheets and the effects of the north-south compression. The north-south structures will not be analyzed in this paper.

During the east-directed thrust sheet emplacement, frontal and lateral ramps developed within the hangingwall of the Ponga Unit on a number of scales (Fig. 4 and 5). For example, a large frontal ramp such as the one related to CaT (section 2, Fig. 4) cuts through the entire stratigraphic sequence. However, the staircase trajectory of thrusts is partially controlled by the stratigraphy in many thrust faults. Frequently, a lower frontal ramp cuts through the Cambro-Ordovician succession and a flat has developed at the top of the Ordovician Barrios Formation (e.g. in LT, AT, and VT thrusts in section 2, Fig. 4).

A three-dimensional staircase trajectory of the sole thrust of the Ponga Unit can be deduced from the balanced cross-sections. A lower frontal footwall ramp up to $3 \mathrm{~km}$ high in the sole thrust occurs in all three sections (ramps a-b in Fig. 4) and a footwall flat located at approximately 2,500 $\mathrm{m}$ depth extends to the east (flat b-c in Fig. 4). These lower frontal footwall ramps in sections 1,2 and 3 have dips of $32^{\circ}, 21^{\circ}$ and $13^{\circ}$ respectively. An upper frontal footwall ramp reaches the surface in the easternmost part of sections 1 and 2. The previously emplaced thrust sheets of the Ponga Unit accommodate to this three-dimensional geometry of the sole thrust by passive rotation, producing fault-bend folding of the entire hangingwall package.

The three-dimensional geometry of the basal thrust of the Ponga Unit is shown in Fig. 6A. This map also shows the minimum deduced extension of the footwall rocks (Pisuerga-Carrion Unit) buried underneath the Ponga Unit. The branch line in this map resulted from joining all "a" points from all sections and the cutoff line resulted from joining all 'b' points from all sections. The tectonic transport arrows, obtained from field data such as cut-off lines, fold axes, minor shear bands and orientation of map scale thrust structures, (Alvarez-Marron 1989) are convergent towards the east (Fig. 6a). The ramps located at high angles (subperpendicular) to the arrows are considered to be frontal ramps and the ones at low angles (sub-parallel) are considered to be lateral ramps. The angles between lateral and frontal ramps varies from about $70^{\circ}$ to less than $40^{\circ}$ with the angles generally smaller towards the south. Three lateral ramps can be seen on this map. The Rio Color and Rio Monasterio lateral ramps (Fig. 5) are the largest with a minimum length of 15 and 20 $\mathrm{km}$, respectively. They have a height of ca. $3 \mathrm{~km}$ in cross-section view (sections 4, 5 and 6 in Fig. 5). Figure $6 \mathrm{~b}$ shows the idealized three-dimensional geometry of the basal thrust of the Ponga Unit prior to deformation, with the frontal ramps perpendicular to lateral ramps.

There are also other lateral ramps within the hangingwall of the Ponga Unit. Most are within individual thrust sheets, although some involve several thrust sheets. For example, the stack of thrust sheets (Beyos Duplex) containing mainly Carboniferous limestones (Barcaliente Fm.) in the frontal part of section 2 
is not present in sections 1 and 3 (Fig. 4) due to the existence of two large tear-faults, the Rio Color and Rio Monasterio tear-faults. These structures are tectonically superposed onto the Rio Color and Rio Monasterio lateral ramps previously described (see the lateral termination to the north and south of the Beyos Duplex in Fig. 3b). The Rio Monasterio tear-fault is also responsible for the lateral termination at the south ends of the ET, AT, CT, VT, and ST thrust sheets (Fig. 3b and section 6 in Fig. 5). The Cofiñal lateral ramp seen on section 5 (Fig. 5) is responsible for the lateral termination to the south of RT and CaT thrust sheets. Most of these major lateral ramps have associated extensional faults ('drop faults' of Butler, 1982b). Minor lateral ramps within the individual thrust-sheets also exist.

\section{EXAMPLES OF FAULT-RELATED FOLDING IN THE PONGA REGION}

The three-dimensional staircase trajectories of thrusts together with the large tectonic superposition of thrust sheets has produced a complex interference pattern of fault related folds in the Ponga Unit. This gave rise to a diverse distribution of kilometric scale folds (Fig. 7) which have variable geometry that can be analyzed only by a detailed three-dimensional analysis of thrust surfaces (Figs 3A, 4 and 5). The construction of cross-sections and cut-off line maps allows these folds to be classified into fault-bend folds related to varied orientations of ramps. Frontal and lateral fault-bend folds are those formed over frontal and lateral ramps and corner folds form at the intersection between frontal and lateral ramps (Fig. 7). For the description that follows each of these three groups of folds are further divided into folds related to footwall and hangingwall ramps. Throughout this paper the terms antiform and synform are used when folds have stratigraphic reversals due to thrust stacking.

\section{$\underline{\text { Frontal folds }}$}

Most of the frontal folds related to footwall ramps in the Ponga Unit, such as the wide synform folding the CaT and the wide antiform folding the ET in section 2 (Fig. 4), are geometrically necessary bends obtained during construction of balanced cross-sections. They are buried underneath other thrust sheets and their axial traces are not observed at the surface. The frontal folds related to footwall ramps have large interlimb angles that are generally more than $120^{\circ}$.

Due to erosion, most of the frontal hangingwall ramps preserved are in the lower part of the stratigraphic sequence (Cambro-Ordovician rocks and the Lower Carboniferous limestone). The frontal hangingwall-ramp folds can be seen in sections 1 (in CaT, AT, CT thrust sheets) and 2 (in CaT, ET, AT and CT thrust sheets) (Figs. 3A, 4 and 5). The geometry of such folds related to the AT and CT thrust sheets can be directly observed in the field (Fig. 8). In these thrust sheets, the ramps cut through the Cambro-Ordovician rocks and have a short hangingwall flat located near the base of the Carboniferous rocks (Fig. 8). The anticlines in the competent Ordovician quartzite (Barrios Fm.) have interlimb angles of about $120^{\circ}$ whereas the contiguous synclines folding the Carboniferous rocks are tighter, with interlimb angles of $60^{\circ}$ (i.e. syncline in the AT in section 1, Fig. 4 and in Fig. 8). These synclines may have been tightened by the subsequent emplacement of underlying thrusts that outcrop to the east. 
The major antiform at the front of section 2 (Fig. 4), Beyos Antiform (Fig. 7), is also a frontal fold located above a frontal footwall ramp and has produced the back rotation and, also, inversion of strata of ST, VT and CT thrust sheets in its back limb (section 2, Fig. 4). The Beyos Antiform has an amplitude of at least $3 \mathrm{~km}$ and a length along strike of about $12 \mathrm{~km}$, ending laterally to the north and south as a result of the lateral termination of the thrust sheets that form the duplex, Beyos Duplex (Fig. 3B, section 2 in Fig. 4 and Fig. 7).

$\underline{\text { Lateral folds }}$

The Rio Color and Rio Monasterio antiforms (Alvarez-Marron \& Perez-Estaun 1988) are the most prominent lateral folds in the Ponga Unit, with east-west trends and along strike lengths of about $35 \mathrm{~km}$ (Figs. 3a and 7). These folds are related to the Rio Color and Rio Monasterio lateral ramps (Fig. 5 and 6a) and affect the entire thrust pile in the Ponga Unit. The geometry of these large folds varies along strike due to folding of previously formed structures (compare sections 5 and 6, Fig. 5). Both the Rio Color and Rio Monasterio antiforms have been modified and amplified by the subsequent north-south compression, and reverse faults related to this deformation event are common in their cores. The approximately $19 \mathrm{~km}$-wide Beleño Synform occurs between the Rio Color and Rio Monasterio antiforms, in which a thick package of Carboniferous rocks is preserved within the Beleño and Coballes basins (Fig. 3).

North of the Rio Color antiform in the eastern part of the map there is a narrow (about $3 \mathrm{~km}$ wide) synform (Sebarga Synform section 4 Fig. 5), in which unconformable Stephanian sediments are preserved (Fig 3). The northern limb of the Sebarga Synform constitutes a lateral culmination wall formed by the Sebarga thrust as a result of the southern lateral termination of the Tornin Thrust System (Figs. 3b and 5).

In the whole southern part of the Ponga Unit, the north-south compressional deformation produced a large variation in the original angles making the discrimination between lateral and frontal structures uncertain. For example, south of the Rio Monasterio Antiform most angles between lateral and frontal folds on the map range from $60^{\circ}$ to even $30^{\circ}$ (Fig. 7). Only the Tarna Synform and San Isidro Antiform (section 5 in Fig. 5b) are classified as lateral folds with greater confidence. Their western-most part can be related to the San Isidro lateral ramp in the footwall of the Ponga Unit (Fig. 6).

Unequivocal examples of lateral hangingwall folds do not occur in the Ponga Unit, although two anticline-syncline pairs with a trend at high angles to frontal folds within the ET thrust-sheet occur in the Beleño basin (Figs. 3 and 7). These folds are outlined by the calcareous Escalada formation which may be interpreted as lateral hangingwall folds since the corresponding thrust does not draw an equally folded shape. The other example of lateral folds in the Campo de Caso basin are also interpreted as hangingwall lateral folds but their relationship to the corresponding thrust can not be determined because of interference by the Ventaniella Fault.

Corner folds.

A "corner fold" forms at the intersection between lateral and frontal ramps, over the dihedral angle generated by the intersection of the two ramp planes (Alvarez-Marron 1991). Corner folds have axial traces 
that are oblique to the traces of the frontal and lateral folds to which they are related. They form with plunging axes, oblique to the transport direction. The best examples of corner syncline folds are in the eastern part of the Ponga Unit (Fig. 7 and 8). For example, the box-like termination of the Beleño and Sebarga basins in the east is related to the development of corner synclines. These synclines have shorter axial traces and are related to the intersection between footwall frontal and lateral ramps. Other corner folds with short axial traces are present throughout the area (Fig. 7).

The Rio Color, Rio Monasterio, Tarna and San Isidro lateral folds (Fig. 7) form periclines over the corners formed by the intersection of the respective lateral and frontal ramps in the sole thrust of the Ponga Unit (Fig. 6a). These folds bend the entire pile of hangingwall thrust sheets and deform their internal structures.

Examples of corner folds related to intersection of frontal and lateral hangingwall ramps are not found in the Ponga Unit.

\section{FOLD SUPERPOSITION AND INTERFERENCE: DISCUSSION}

The Ponga Unit is a complexly deformed stack of thrust sheets in which the structurally highest thrusts and internal three-dimensional thrust sheet features such as fault-bend folds are deformed by movement over three-dimensional ramps and flats of subsequent thrusts developed in their footwall. This complex deformation has produced folds with diverse orientations and relationships of their axial traces (Fig. 7). Some folds are developed only within the hangingwall of a particular thrust sheet and their axial traces terminate laterally against a thrust; some terminate against other folds. However, fold superposition is widespread and it is common that axial traces continue across more than one thrust sheet, such as those of the major east-west trending folds (Fig. 7). Along the trace, variation of fold plunge is frequent in folds of all orientations. Typical examples of the effects of two-dimensional superposition of fault-bend folds predicted by Suppe's models (1983), such as back rotation and tightening of folds are common. However, this paper has focused on examples of the three-dimensional interference and superposition of fault-bend folds.

The three-dimensional effect of the interference between a lateral and a frontal ramp on the hangingwall geometry depends on the amount of displacement of the thrust (Fig. 9), and there are two general categories:

1. Where the displacement of the thrust is less than the length of the lateral ramp there may be along-strike termination of frontal folds (Fig. 9b). This aligned termination of frontal folds outlines the location of the lateral ramp below (Wilson \& Stearns 1958).

2. Where the displacement of the thrust approaches or is greater than the length of the lateral ramp a lateral fold forms. The axial-trace length of a lateral fold reaches its maximum length when the slip is larger than the length of the lateral ramp (Fig. 9c). If the displacement of the thrust is oblique to the ramp then the amount of displacement relative to ramp length needed to form a fault-bend fold is reduced. Barrete (1988) has described the formation of folds over oblique ramps for small displacements.

To illustrate the three-dimensional interference and superposition of fault-bend folds related to lateral and frontal ramps a series of models have been constructed (Figs. 10 and 11). These correspond to 
examples in the Ponga Unit and are described in the following text. The diagram in Fig. 10A illustrates two types of interaction between lateral and frontal structures as the hangingwall moves over a three-dimensional staircase thrust surface:

1) The formation of a corner fold as a consequence of the interference between lateral and frontal bends where they join together (marked with arrows 1 and 2, Fig. 10a); and 2) the superposition of frontal and lateral bends (marked with arrow 3, Fig. 10a).

The model in Fig. 10a shows that corner synclines form in the intersection of frontal and lateral footwall ramps when the frontal ramp is at the front of the lateral ramp (marked with a 1 in Fig. 10a). It also shows that corner anticlines form in the intersection of frontal and lateral footwall ramps when the frontal ramp is at the rear of the lateral ramp (marked with a 2 in Fig. 10a). The amplitude and interlimb angle of a corner fold depends on the angle between the intersecting ramp planes. The along-strike continuity of the fold depends on the height of intersecting ramps. The simplest corner fold will form by interaction of lateral and frontal bends related to ramps that have the same height (as the corner folds shown on Fig. 10a). The axial trace of a corner fold merges at its ends with the points where lateral and frontal fold axial traces join together. The rotational history for each limb of a corner fold is likely to be different (Stewart 1993). However, analog models by Apotria et al. (1992) demonstrate that only minor out-of-plane deflection occurs in the hangingwall above an oblique ramp. Recognition of fold type is important prior to interpretation of structural data, such as determining the original position of cut-off lines where the thrust faults have threedimensional staircase trajectories.

A field example of a corner fold similar to that depicted in interaction 1 (Fig. 10a) is the corner syncline at the northeastern end of the Beleño Basin (Fig. 7). The axial trace of this corner syncline merges with the intersection of the axial traces of the Beyos and Rio Color antiforms. However, the corresponding synclinal axial traces at the other end are not seen at the surface because they correspond to buried synformal bends. The folds formed by intersection of two sub-perpendicular sets of folds, called coaptation folds by Stauffer (1988), have been attributed by Lisle et al. (1990) to an isometric bending mechanism.

The periclinal termination of the Rio Color Antiform towards the west is a corner anticline similar to interference 2 in Fig. 10a. It has a conical shape and deforms the entire hangingwall stack of thrust-sheets overprinting the previous structural relationships.

A more complex interaction between frontal and lateral folds occurs where these bends are related to two non-parallel ramps of different heights. In this case, the axial trace of a corner fold merges from the end of a lateral fold only and no frontal-lateral pair exists (Fig. 10b). An example of this interaction can be found in the Ponga Unit. In the western part of the northern hangingwall panel of Rio Monasterio Antiform, two axial traces of lateral synclines are overstepped by the axial trace of the oblique corner fold that joins them (Fig. 7).

Another complex interaction between lateral and frontal structures is the superposition of frontal and lateral ramps (marked with arrow 3 in Fig. 10a). The two simplest hangingwall situations resulting from the superposition of frontal and lateral ramps of a single thrust fault are shown in Fig. 11. From the models and relationships observed in the Ponga Unit, two general rules can be deduced for the superposition of frontal and lateral bends: 1) where a frontal hangingwall ramp is located above a lateral footwall ramp the axes of 
lateral folds plunge towards the foreland (Fig. 11a); 2) where a lateral hangingwall ramp is located above a frontal footwall ramp the axes of lateral folds plunge towards the hinterland (Fig. 11b). These geometric rules allow differentiation between buried hangingwall lateral ramps and footwall lateral ramps by analyzing the direction of plunge of lateral fault-bend folds. Along-strike changes in the plunge of frontal fold axes does not provide a means of discriminating between buried footwall and hangingwall lateral ramps.

Several examples of frontal folds over lateral hangingwall panels (Fig. 11a) can be found in the Ponga Unit. The best of which is illustrated by the detailed map of Fig. 8. The axes of these frontal folds in the AT and CT thrust sheets plunge $30^{\circ}$ to $40^{\circ}$ towards the south on the lateral culmination-wall related to the Rio Color lateral ramp. Examples of lateral folds over frontal hangingwall panels (Fig. 11b) are less common although the two anticline-syncline pairs within the ET thrust sheet in the Beleño Basin (Fig. 7) may be included in this type of superposition. Their axes plunge about $25^{\circ}$ degrees towards the west.

The characteristics of the folds described above and their relationships to thrust fault geometry indicate that most map scale folds in this region formed as fault-bend folds. However, the original fault-bend fold geometry in frontal hangingwall ramp folds in the Ponga Unit was modified by simple shear parallel to the movement direction of thrust faults. Major lateral folds have been tightened and locally overturned due to post-emplacement north-south compression (Alvarez-Marron 1988). This north-south deformation has also modified the original angular relationships between frontal and lateral structures by a considerable amount in the southern part of the area.

\section{CONCLUSIONS}

The arcuate shape of the Variscan Orogen in NW Spain resulted in the complex structure exhibited by the Cantabrian foreland thrust and fold belt. The complex superposition of structures formed as a consequence of differing shortening directions. The quality of the outcrops and the constraints on the deep structure provided by erosional windows into the cores of well-developed lateral folds make the $\mathrm{CZ}$ an exceptional area for analyzing the three-dimensional geometry and interference of foreland thrust-belt structures.

Despite the complex superposition of structures found in the Cantabrian Zone, the cross-folding pattern in the Ponga Unit can be interpreted as being mainly the result of interference and superposition of fault-bend folds related to three-dimensional trajectories of east-directed thrust faults, subsequently overprinted by north-south shortening. Frontal and lateral fault-bend folds are common and corner folds have formed over the intersection of frontal and lateral fault-bend folds. The corner folds have plunging axes oblique to the tectonic transport direction. Superposition of lateral and frontal bends produces changes in the plunge of fold axes. The superposition of a frontal hangingwall ramp over a lateral footwall ramp produces foreland plunging axes in the corresponding hangingwall lateral folds. The superposition of a lateral hangingwall ramp over a frontal footwall ramp produces hangingwall lateral folds that plunge towards the hinterland. This geometric rules allow differentiation between buried hangingwall lateral ramps and footwall lateral ramps. A three-dimensional geometric and kinematic analysis of fault topography carried out by the construction of balanced cross-sections and cut-off line maps allows the determination of the type of 
interference and superposition. The recognition of fold type is important for accurate interpretation of buried thrust fault geometry.

Acknowledgments- This work forms part of a Ph.D. thesis supervised by A. Perez-Estaun and J. L. Alonso. They are also thanked for critically reading an earlier version of the manuscript. The Ph.D. project was funded by the Spanish Ministry of Education and Science. D. Brown is thanked for helping with several versions of the manuscript. M.R. Stauffer and G. Roberts are thanked for their insightful reviews.

\section{REFERENCES}

Aller, J. 1986. La estructura del sector meridional de las unidades del Aramo y Cuenca Carbonífera Central. Servicio de Publicaciones del Principado de Asturias, $180 \mathrm{p}$.

Alonso, J. L. 1987. Sequences of thrusts and displacement transfer in the superposed duplexes of the Esla Nappe Region (Cantabrian Zone, NW Spain). J. Struct. Geol. 9, 969-983.

Alonso, J. L., Pulgar, J. A., Garcia-Ramos, J. C. and Barba, P. in press. Tertiary basins and alpine tectonics in the Cantabrian Mountains (NW Spain). In: Tertiary Basins of Spain. Tectonics, climate and sea-level changes. (edited by Friend P. F. \& Dabriao C.). Cambridge University Press.

Apotria, T., Snedden, W. T., Spang, J. H. and Wiltschko, D. V. 1992. Kinematic models of deformation at an oblique ramp. In: Thrust Tectonics (edited by McClay K. R.). Chapman and Hall, London, 141-154.

Alvarez-Marron, J. 1989. La estructura geológica de la Región del Ponga (Zona Cantábrica, NW de España). Servicio de Publicaciones de Tesis Doctorales, Universidad de Oviedo.

Alvarez-Marron, J. 1991. 3D geometries and distribution of fault-bend folds related to thrust topography: examples from the Cantabrian zone, NW Spain. John Ramsay Meeting, ETH, Zurich, Neue Folge 239b, 93 (abstract).

Alvarez-Marron, J. y Perez-Estaun, A. 1988. Thin-skinned tectonics in the Ponga Region (Cantabrian Zone, NW Spain). Geologische Rundschau 77, 539-550.

Barrete, P. D. 1988. Internal geometry and origin of the Hubat structural culmination, Oman Mountains. $J$. Struct. Geol. 10, 383-391.

Bastida, F. and Castro, S. 1988. Estructura del sector septentrional de la Escama de Tameza (Zona Cantábrica, NW de España). Trab. Geol. Univ. Oviedo 17, 67-85.

Berger. P. and Johnson, A. M. 1980. First-order analysis of deformation of a thrust sheet moving over a ramp. Tectonophysics 70, 9-24.

Butler, R. W. H. 1982a. Hangingwall strain: a function of duplex shape and footwall topography. Tectonophysics 88, 235-246.

Butler, R. W. H. 1982b. The terminology of structures in thrust belts. J. Struct. Geol. 4, 239-245.

Cooper, M. A. 1983. The calculation of bulk strain in oblique and inclined balanced sections. J. Struct. Geol. 5, 161-165.

Coward, M. P. and Potts, G. J. 1985. Complex strain patterns developed at the frontal and lateral tips to shear zones and thrust zones. J. Struct. Geol. 5, 383-399. 
Elliott, D. and Johnson, M. R. W. 1980. Structural evolution in the northern part of the Moine thrust belt, NW Scotland. Trans. R. Soc. Edinb. 71, 69-96.

Geiser, P. 1988. The role of kinematics in the construction and analysis of geological cross sections in deformed terranes. Geol. Soc. Am. Special Paper 222, 47-75.

Jamison, W. 1987. Geometric analysis of fold development in overthrust terranes. J. Struct. Geol. 9, $207-219$.

Julivert, M. 1960. Estudio geológico de la cuenca de Beleño, valles altos del Sella, Ponga, Nalón y Esla de la Cordillera Cantábrica. Bol. Ins. Geol. Min. España, LXXI, 1-346.

Julivert, M. 1971. Decollement tectonics in the Hercynian Cordillera of Northwestern Spain. Am. J. Sci. 270, $1-29$.

Julivert, M. and Marcos, A. 1973. Superimposed folding under flexural conditions in the Cantabrian Zone (Hercynian Cordillera, NW Spain). Am. J. Sci. 273, 353-375.

Lisle, R. J., Styles, P. and Freeth, S. J. 1990. Fold interference structures: the influence of layer competence contrast. Tectonophysics 172, 197-200.

Marcos, A. and Pulgar, J. A. 1983. An approach to the tectonostratigraphic evolution of the Cantabrian Foreland thrust and fold belt, Hercynian Cordillera of NW Spain. N. Jb. Geol. Palaont. 163, 256-260.

Mitra, S. 1988. Three-dimensional geometry and kinematic evolution of the Pine Mountain thrust system, southern Appalachians. Bull. geol. Soc. Am. 100, 72-95.

McClay, K. R. and Coward, M. P. 1981. The Moine Thrust Zone. An overview. In: Thrust and Nappe Tectonics (edited by McClay K. R. \& Price N. J.). Spec. Publs geol. Soc. Lond. 9, 241-260.

Perez-Estaun, A., Bastida, F., Alonso, J. L., Marquinez, J., Aller, J., Alvarez-Marron, J., Marcos, A. and Pulgar, J. A. 1988. A thin-skinned tectonic model for an arcuate fold and thrust belt: Cantabrian Zone. Tectonics 7, 517-537.

Perez-Estaun, A., Pulgar, J. A., Banda, E., Alvarez-Marron, J. and ESCI-N Research Team 1994. Crustal structure of the external Variscides in NW Spain from deep seismic reflection profiling. Tectonophysics 232, in press.

Ramsay, J. G., Casey, M. and Kligfield, R. 1983. Role of shear in development of the Helvetic fold-thrust belt of Switzerland. Geology 11, 439-442.

Rich, J. L. 1934. Mechanics of low-angle overthrust faulting as illustrated by the Cumberland Thrust Block, Virginia, Kentucky and Tenessee. A. A. P. G. Bull. 18, 1584-1596.

Stewart, S. A. 1993. Fold interference structures in thrust systems. Tectonophysics 225, 449-456.

Stauffer, M. R. 1988. Fold interference structures and coaptation folds. Tectonophysics 149, 339-343

Suppe, J. 1979. Fault-bend folding. Geol. Soc. Am. Abs. w. Prog.11, p. 525.

Suppe, J. 1983. Geometry and kinematics of fault-bend folding. Am. J. Sci. 283, 684-721.

Suppe, J. 1985. Principles of Structural Geology. Prentice Hall Inc., Englewood Cliffs, New Jersey.

Suppe, J. and Chang, Y. L. 1983. Kink method applied to structural interpretation of seismic sections, western Taiwan. Petroleum Geology of Taiwan 19, 29-49.

Suppe, J., Chou, G. T. and Hook, S. C. 1992. Rates of folding and faulting determination from growth strata. In: Thrust Tectonics (edited by McClay K. R.). Chapman and Hall, London, 141-154. 
Truyols, J. and Sanchez, L. 1983. El Carbonífero Inferior y Medio de la Región de pliegues y Mantos. $X$ Congr. Int. Estrat. Geol. Carbo., Carbonífero y Pérmico de España II, 6, 39-59. I.G.M.E.

Villa, E and Heredia, N. 1988. Aportaciones al conocimiento del Carbonífero de la Región de Mantos y de la Cuenca Carbonífera Central (Cordillera Cantábrica, NO de España). Bol. Geol. Min., T.XCIX-V, 757-769.

Wilkerson, M. S., Medwedeff, D. A. and Marshak, S. 1991. Geometrical modeling of fault-related folds: a pseudo-three-dimensional approach. J. Struct. Geol. 13, 801-812.

Wilson, C. W. Jr. and Stearns, R. G. 1958. Structure of the Cumberland Plateau, Tenessee. Bull. geol. Soc. Am. 69, 1283-1296.

Zamarreño, I. and Julivert, M. 1967. Estratigrafía del Cámbrico del oriente de Asturias y estudio petrográfico de las facies carbonatadas. Trab. Geol. Univ. Oviedo 1, 135-163.

\section{FIGURE CAPTIONS}

Fig. 1 Geological map of the Cantabrian Foreland Thrust and Fold Belt showing the arcuate disposition of major tectonic units. Dashed box indicates the location of the Ponga Unit.

Fig. 2. Representative stratigraphic column for the Ponga Unit (after Truyols \& Sanchez 1983; Zamarreño \& Julivert 1967). The thickness of Cambro-Odovician formations (preorogenic sequence) decreases to ca. $200 \mathrm{~m}$ in the eastern-most thrust sheets.

Fig. 3. A) Simplified geological map of the Ponga Unit. B) Distribution of thrust sheets in the Ponga Unit and location of cross-sections in Figs. 4 and 5. Dashed line represents the location of the Ventaniella Fault, a late Hercynian right-lateral strike-slip fault whose horizontal slip of about $3 \mathrm{~km}$ has been restored in order to help correlation of thrust sheets across it. AT, Aves Thrust; BD, Beyos Duplex; CT, Carangas Thrust; CaT, Campo de Caso Thrust; ET, Espinaredo Thrust; LT, Laviana Thrust; LwT, Lower Thrusts; RT, Rioseco Thrust; ST, Sebarga Thrust; TTS, Tornin Thrust System; VT, Viboli Thrust. PCU, Pisuerga-Carrion Unit. VF, Ventaniella Fault.

Fig. 4. Dip-balanced geological cross-sections. See Fig. 3 for location and initials of thrusts. The restoration of VT displacement produces an increase in the length of sections 2 and 3 (area X within VF vertical lines).

Fig. 5. Oblique geological cross-section. These sections are not plane strain sections and are therefore not balanced sensu stricto. However, locations of structures and thickness of units were constrained using cut-off line maps and iterative construction and restoration of the dip-sections so that the whole restored in three dimensions. Legend as in Fig. 4. See Fig. 3 for location and initials of thrusts. Some geological features in sections 5 and 6 are not in Fig. 3; these are from Aller (1986). Blank areas in sections 4 and 6 correspond to complex small scale duplexing

Fig. 6. A) Sole thrust branch-line and cut-off line map showing distribution of footwall rocks (shaded area) underneath the Ponga Unit. Darker shade highlights the lowest ramps (a-b) areas. The Ventaniella fault is restored. B) Block diagram showing the possible geometry of the sole thrust of the Ponga Unit before the north-south compressional deformation.

Fig. 7. Fold axial trace distributions in the Ponga Region. Ventaniella Fault restored. 
Fig. 8. Detailed map of an area in the southern limb of Rio Color lateral culmination (see Fig. 7 for location) displaying mappable cut-off points.

Fig. 9. The along-trace continuity of lateral fault-bend folds depends on the amount of displacement of the thrust. A) Ideal geometry of a thrust with a lateral ramp, B) for short displacements, the hangingwall geometry consists of the along-strike termination of frontal folds. C) for large displacements, lateral folds (sensu stricto) and corner folds form in the hangingwall.

Fig. 10. Block diagram showing interference of fault-bend folds. White arrow indicates direction of tectonic transport. Frontal folds are FF related to frontal footwall ramps and FH related to frontal hangingwall ramps. Lateral folds are LF related to lateral footwall ramps and LH related to lateral hangingwall ramps. Corner folds are $\mathrm{CF}$ and $\mathrm{CH}$ that are related to intersection of footwall and hangingwall ramps respectively.

Fig. 11 Changes in plunge of fold axes due to superposition of lateral and frontal ramps of a single thrust surface. A) The axes of lateral folds related to footwall lateral ramps (LF) plunge towards the foreland over a frontal hangingwall ramp. B) The axis of lateral folds related to hangingwall ramps (LH) plunge towards the hinterland over frontal footwall ramps. 


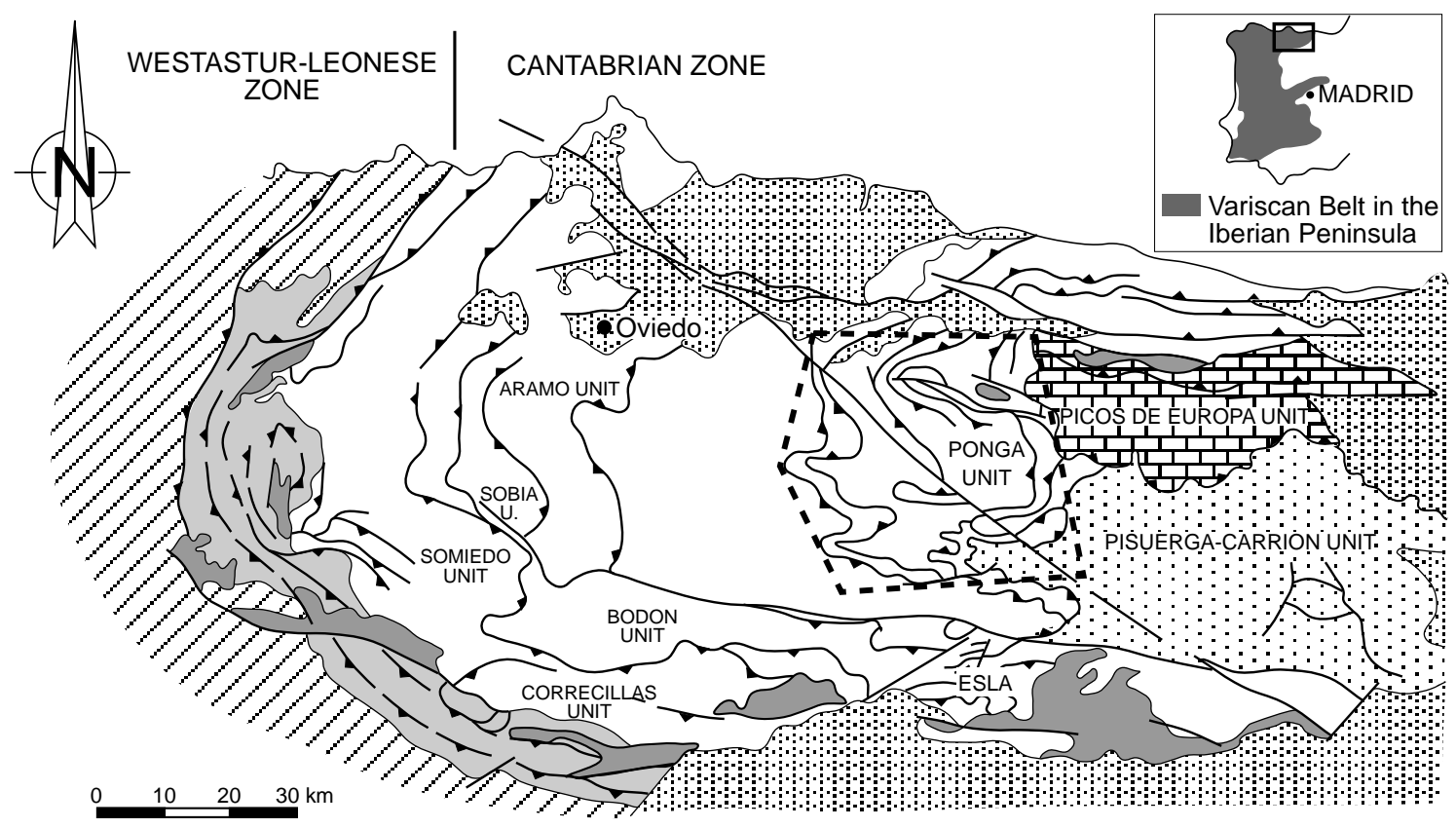

Precambrian rocks (Narcea Antiform)

$\angle Z$ Westasturian-leonese Zone

Unconformable

Stephanian rocks

Undifferentiated Palaeozoic Rocks in the major allochthonous units of the Cantabrian Zone

Meso-Tertiary

Cover

Figure 1. Alvarez-Marron 1994 


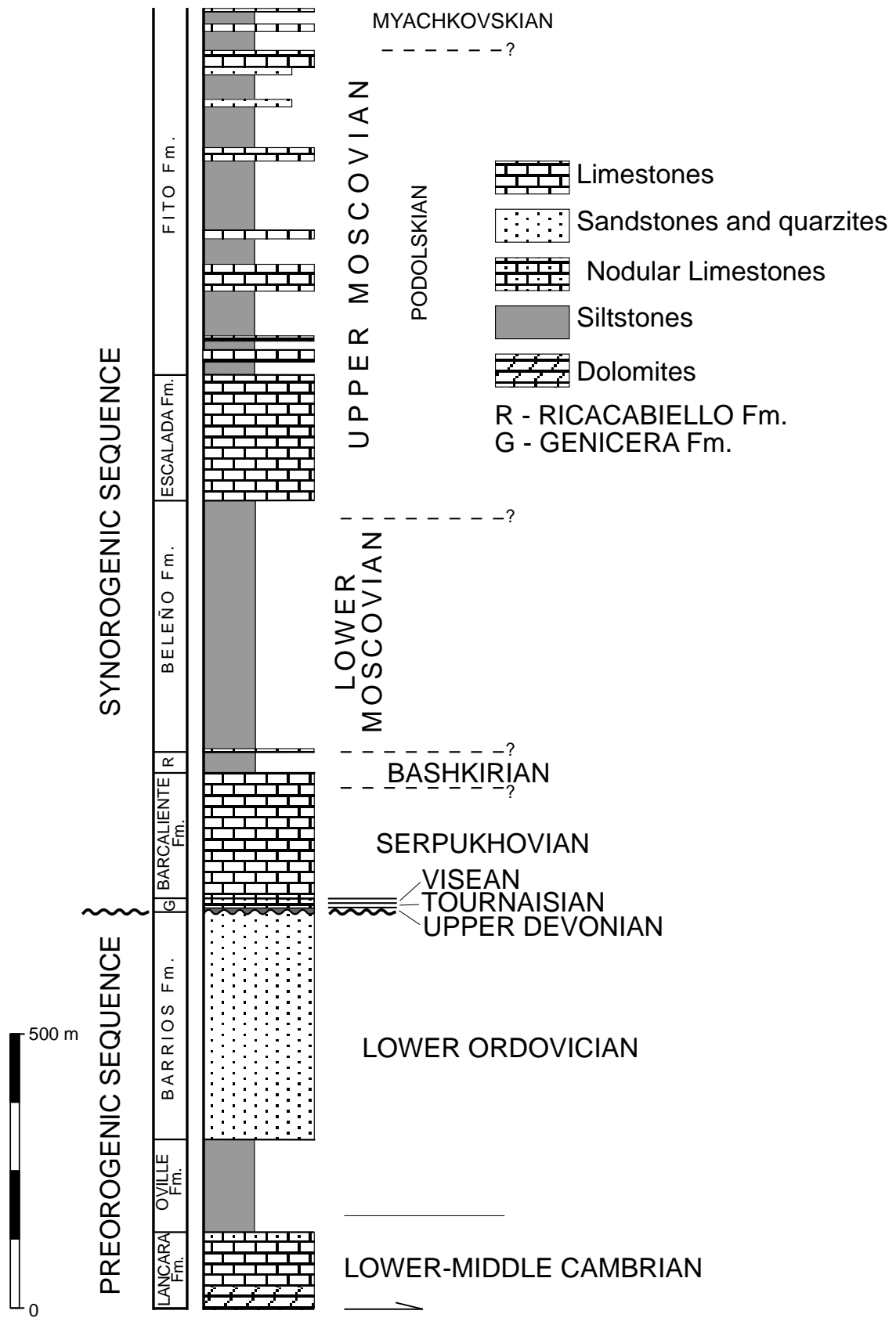

Figure 2. Alvarez-Marron 1994 


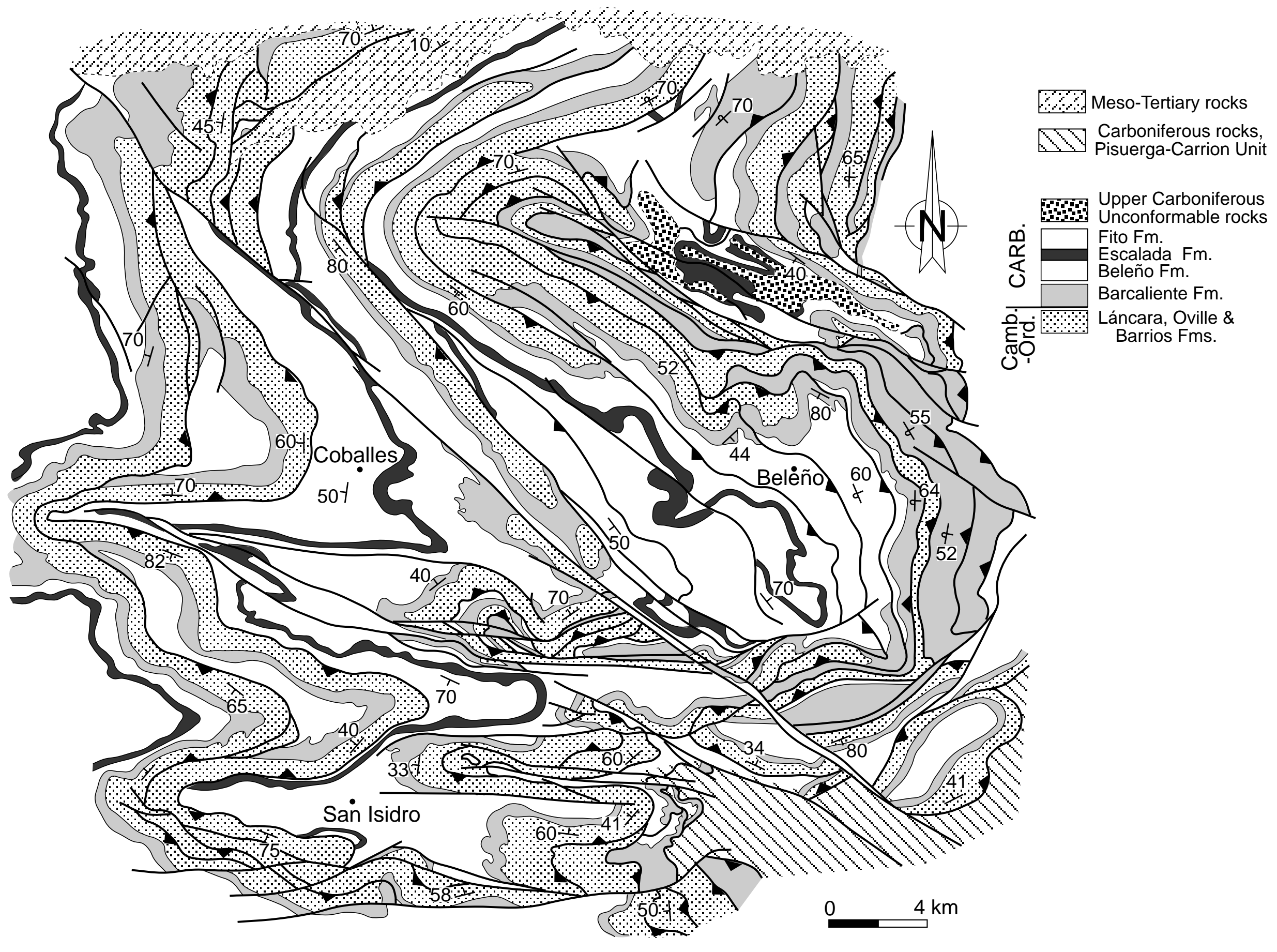




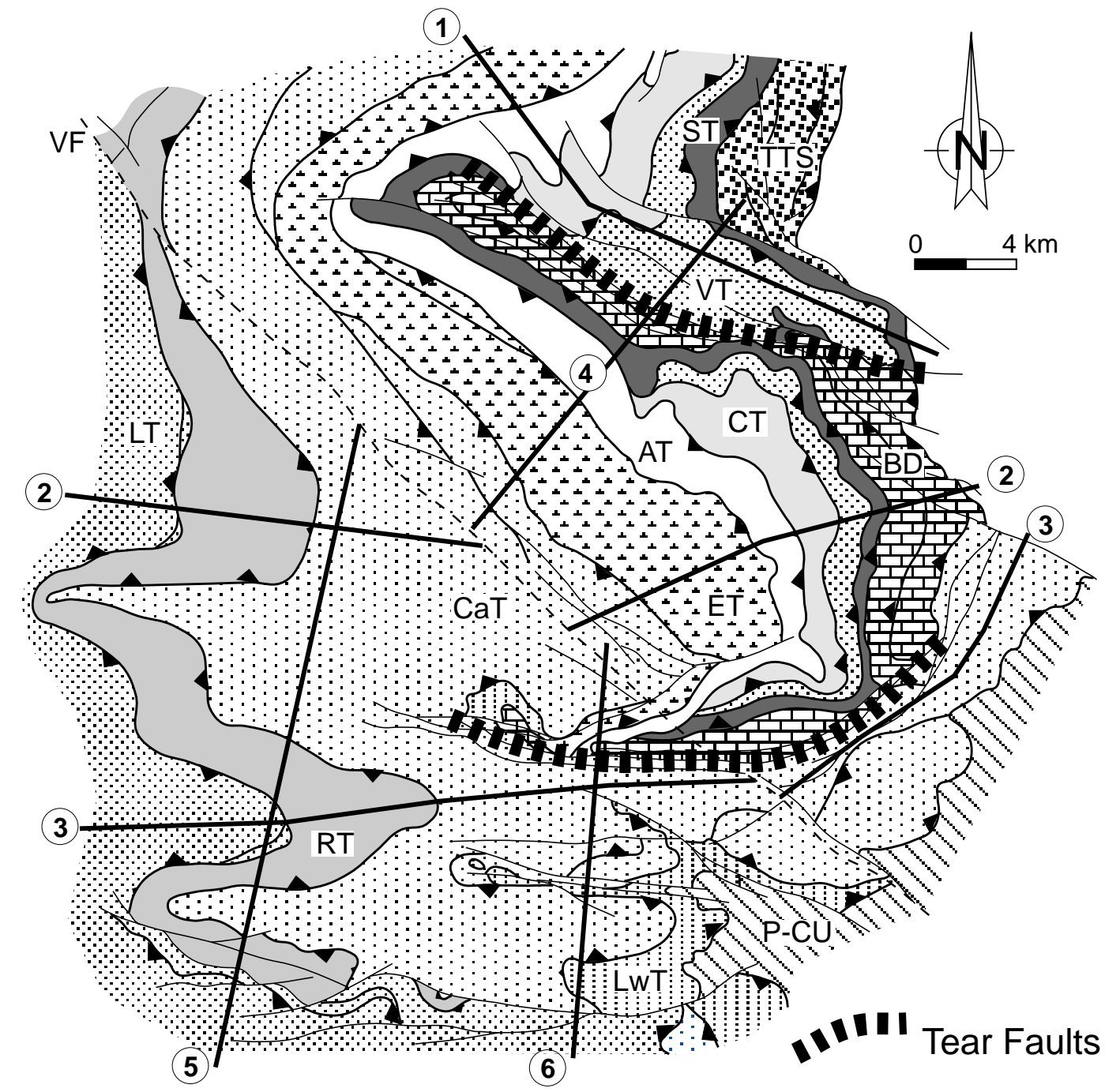

Figure 3B. Alvarez-Marron 1994 

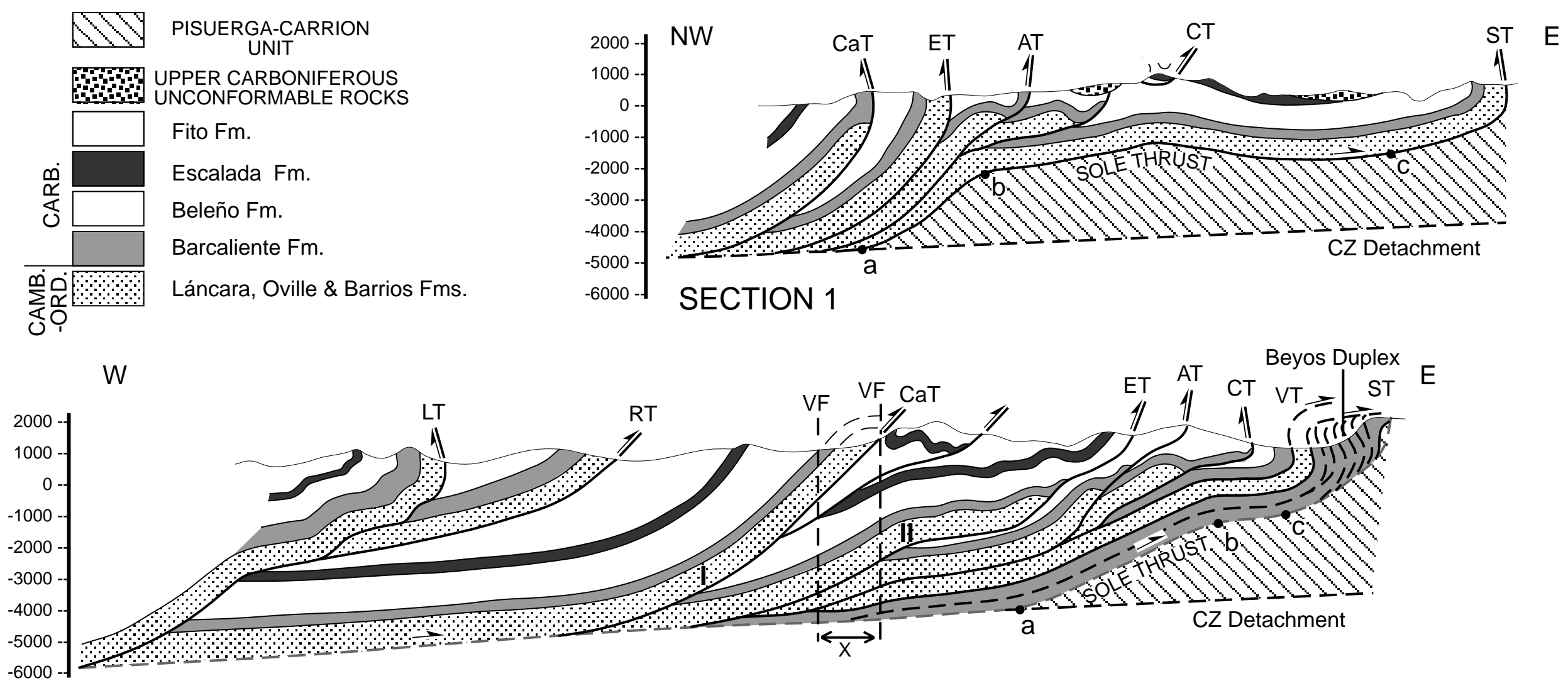

\section{SECTION 2}

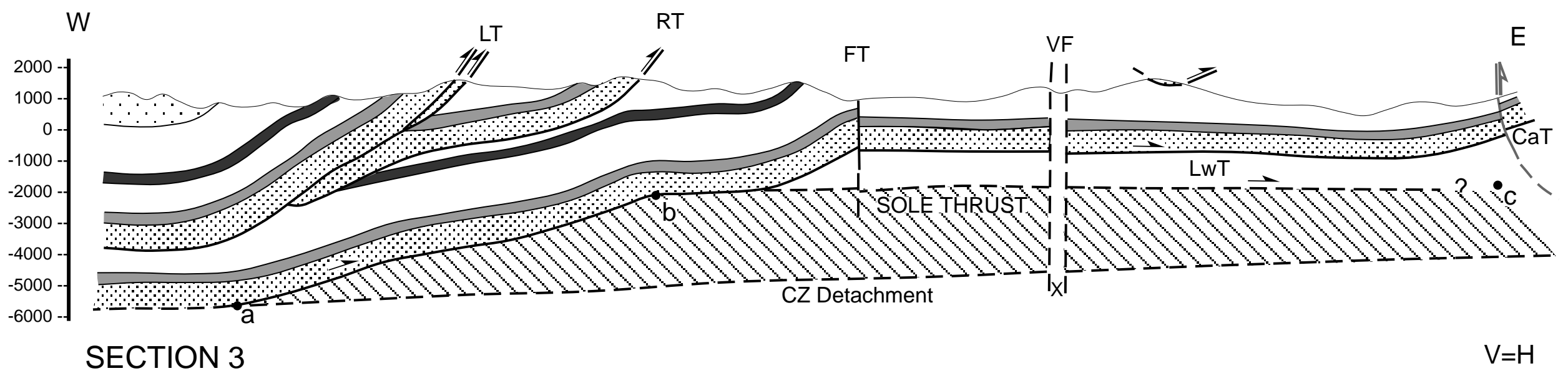

Figure 4. Alvarez-Marron 1994 

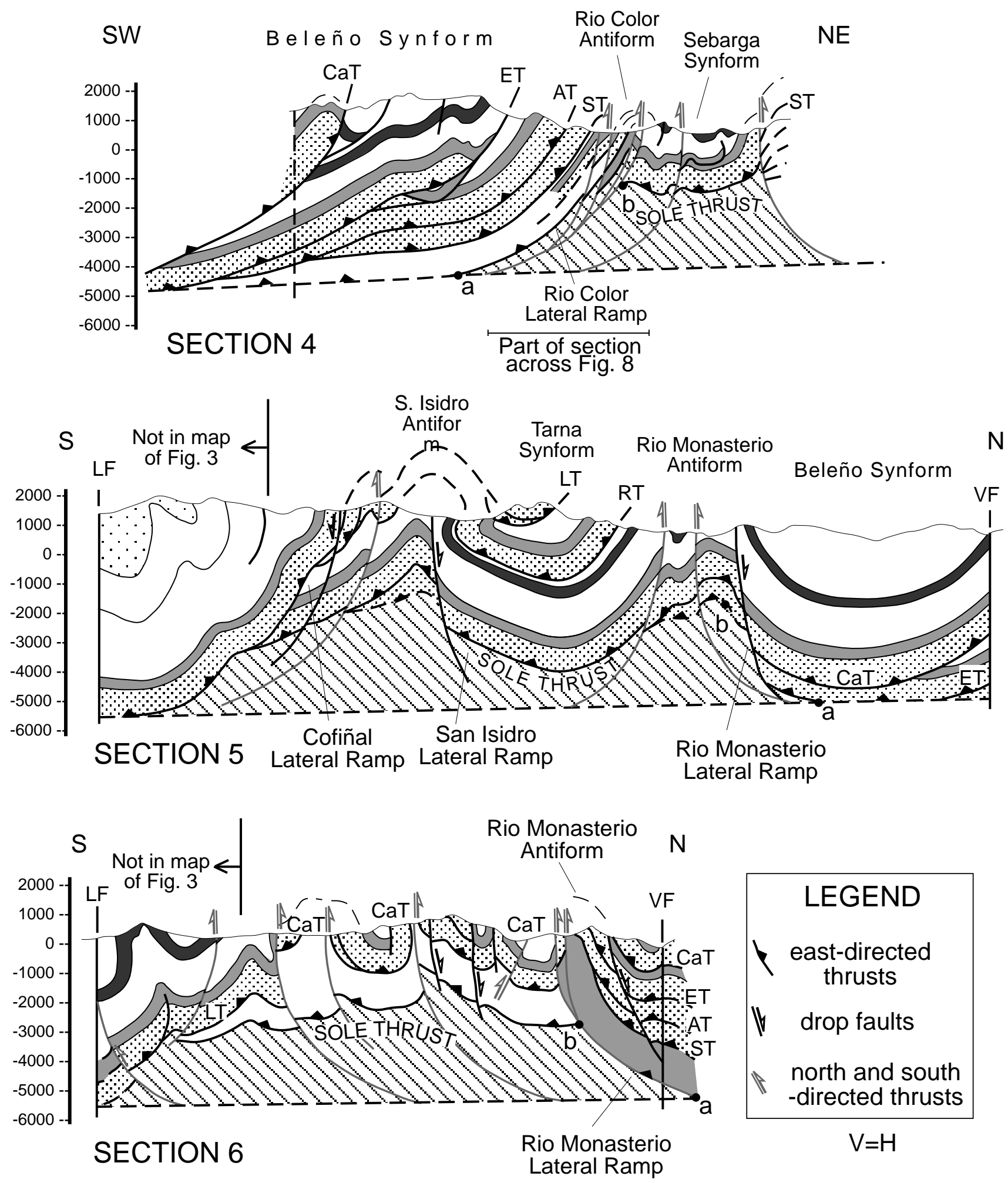


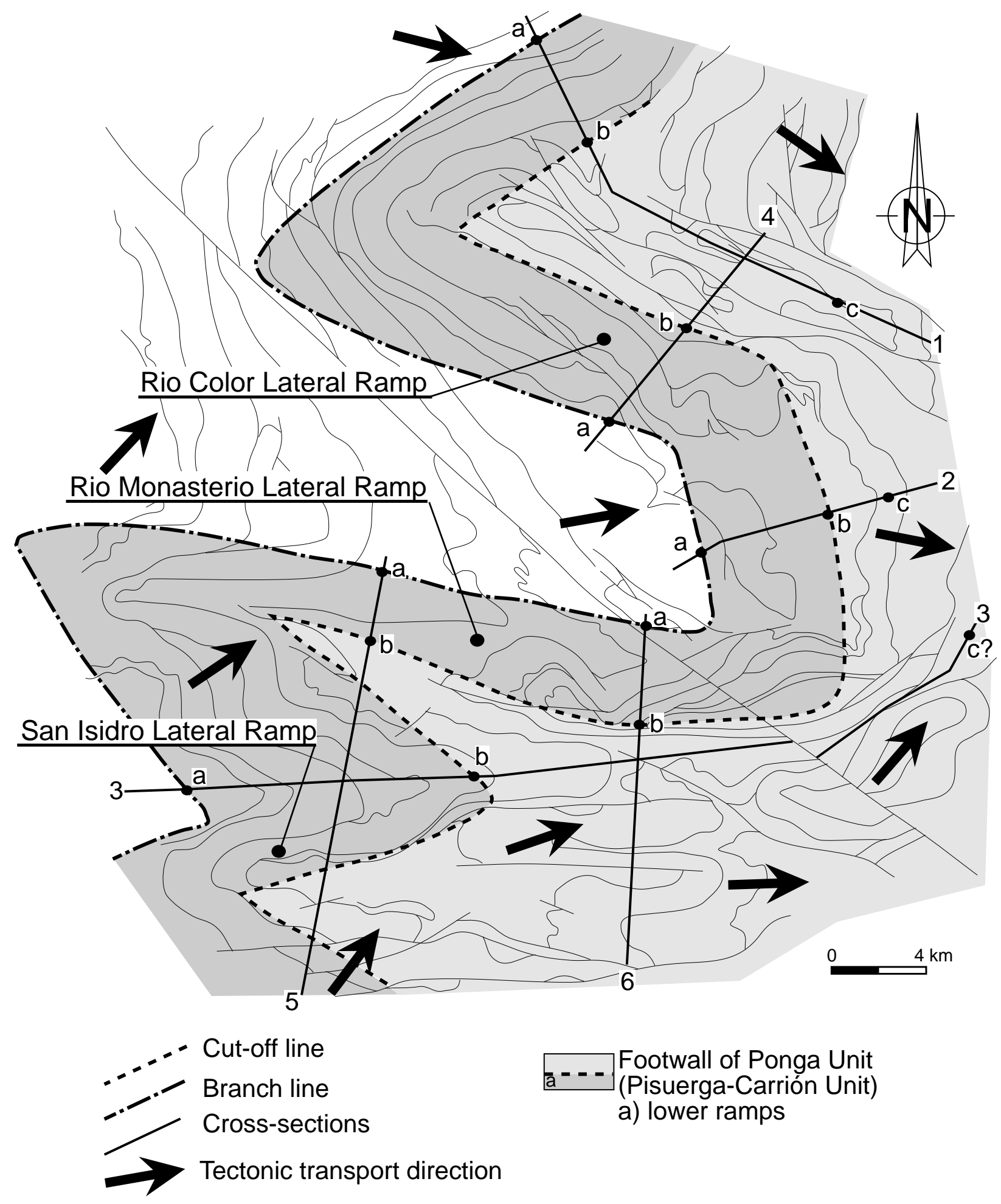

Figure 6A. Alvarez-Marron 1994 


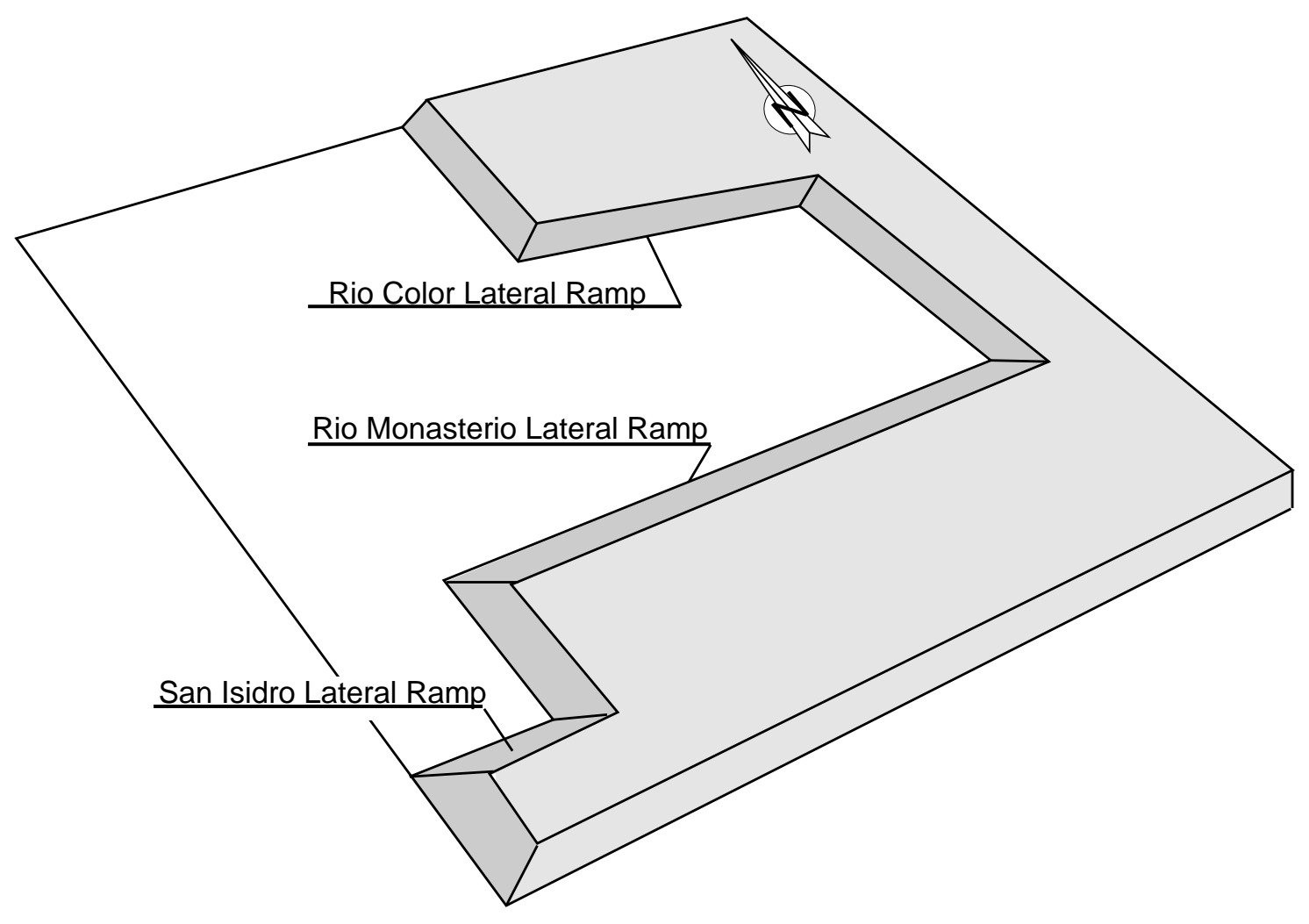

Figure 6B. Alvarez-Marron 1994 


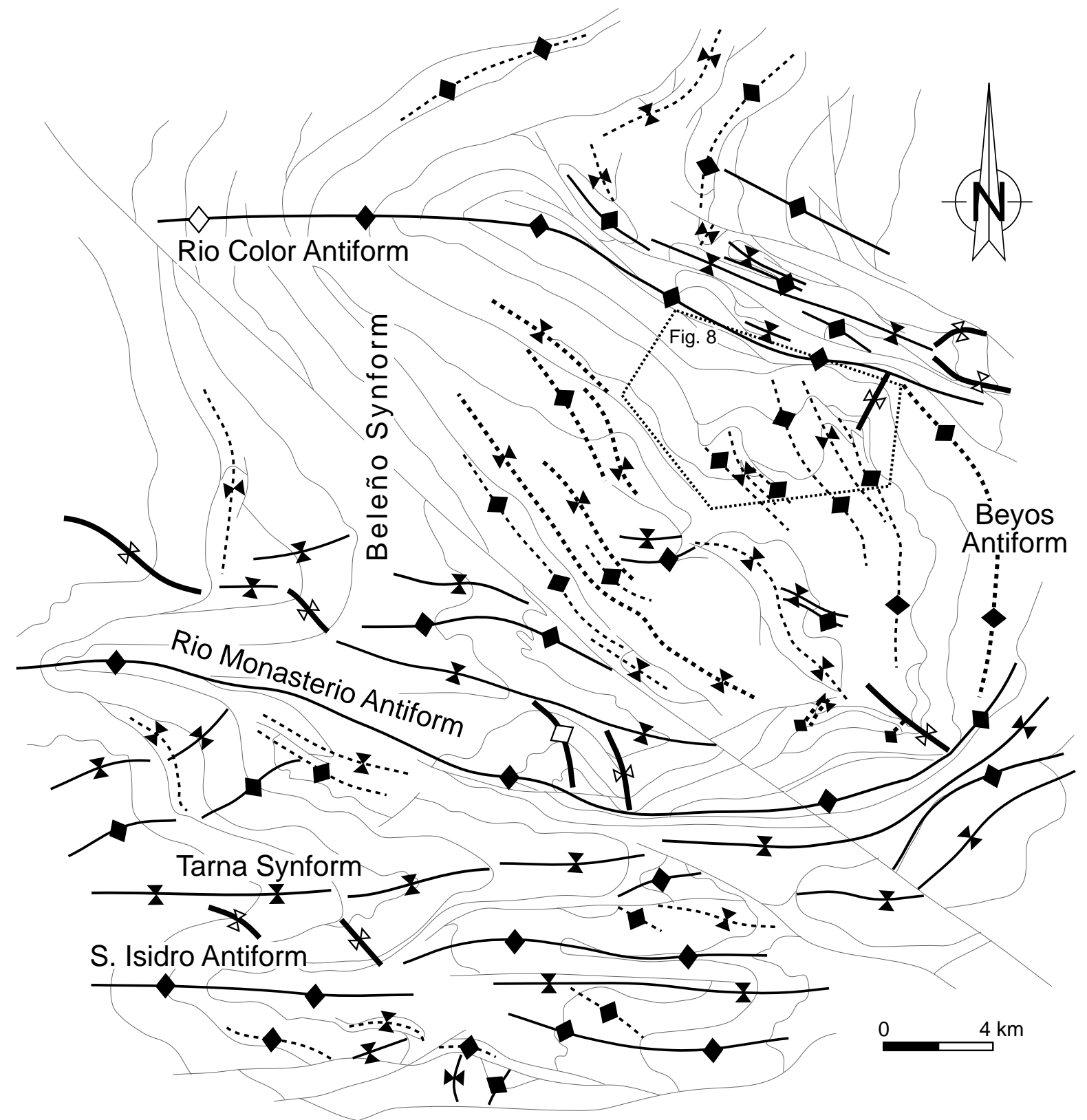

Anticlines and Antiforms Synclines and Synforms

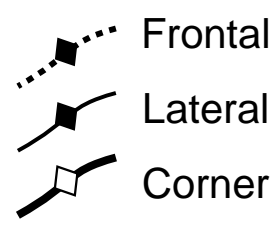

Corner 


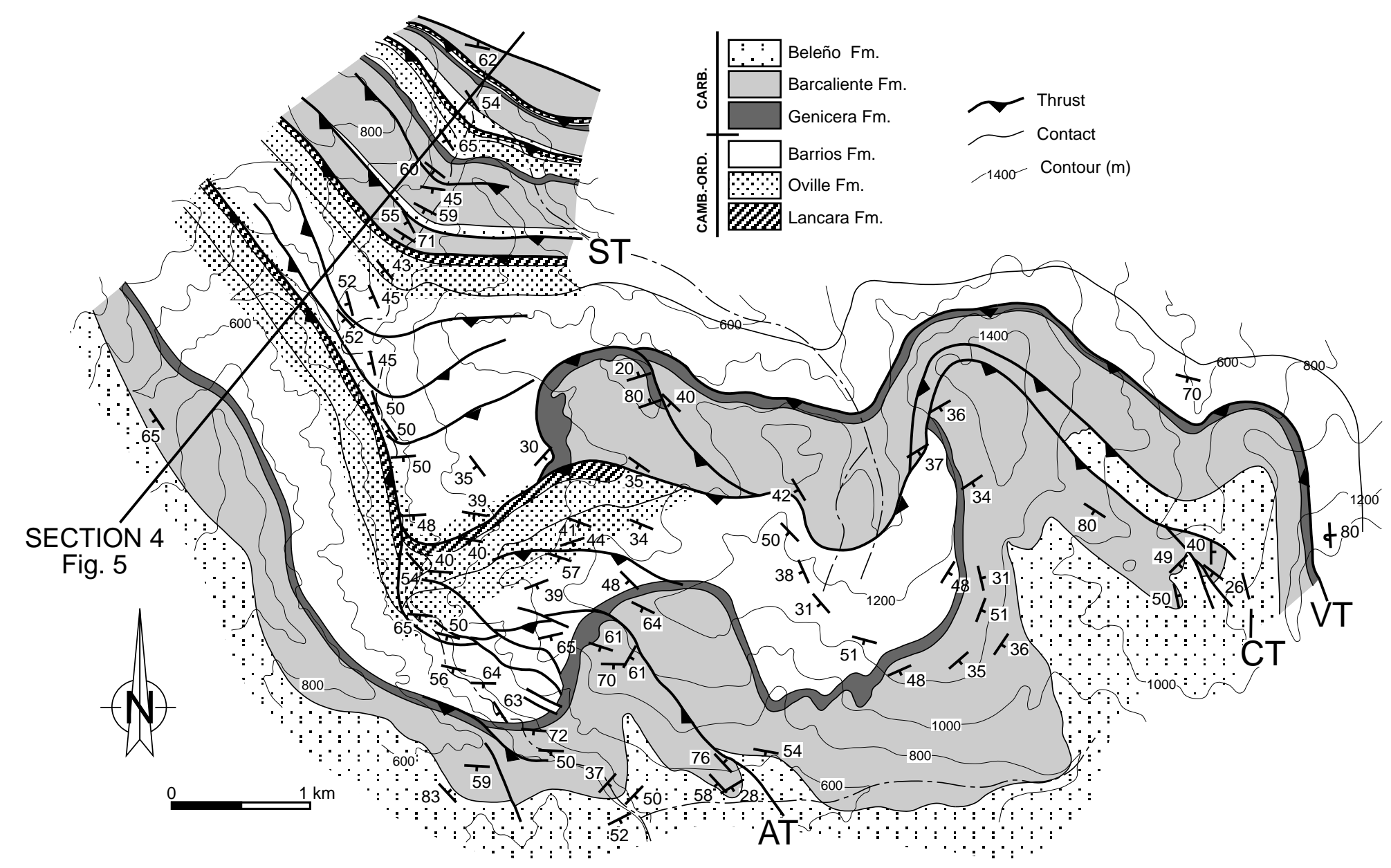

Figure 8. Alvarez-Marron 1994 


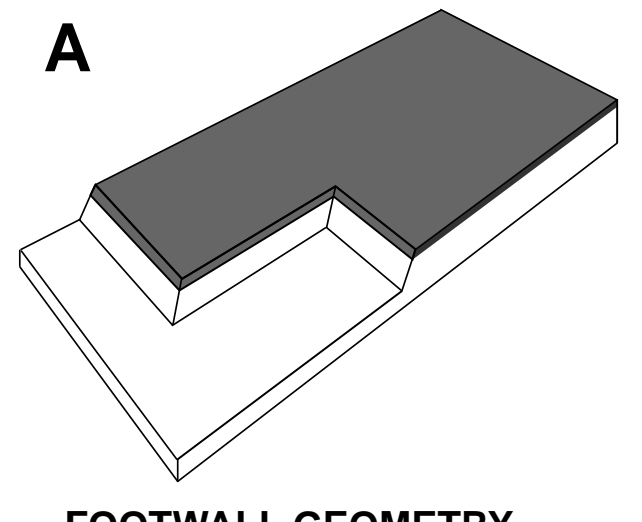

FOOTWALL GEOMETRY
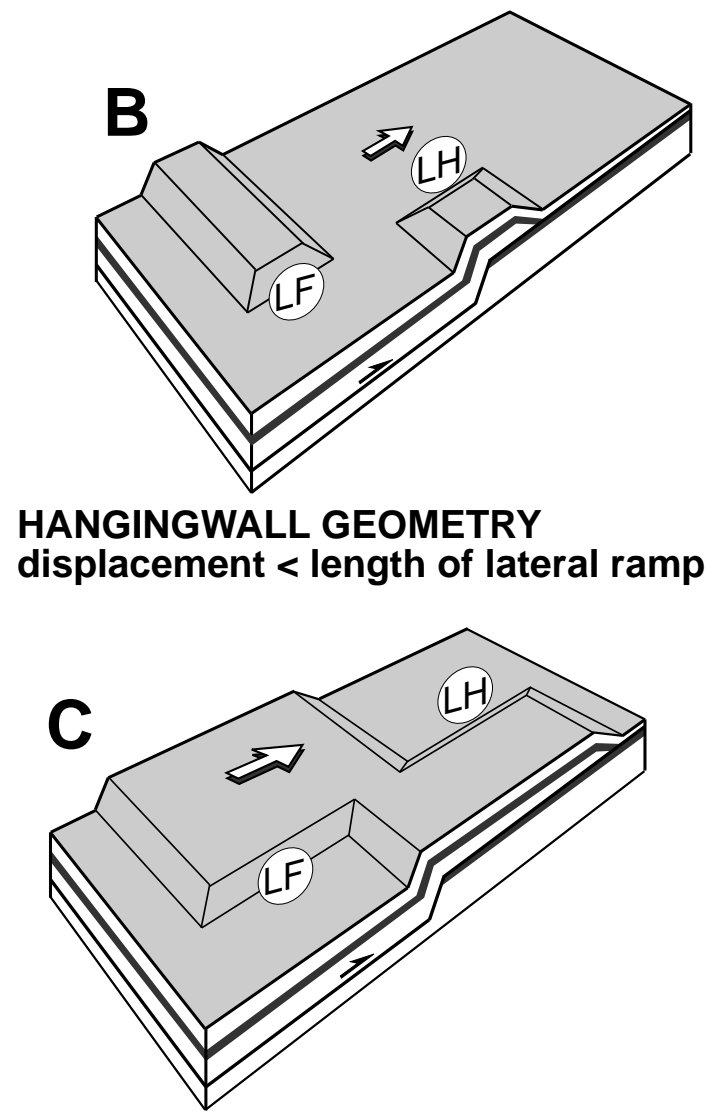

HANGINGWALL GEOMETRY

displacement $>$ length of lateral ramp

Figure 9. Alvarez-Marron 1994 


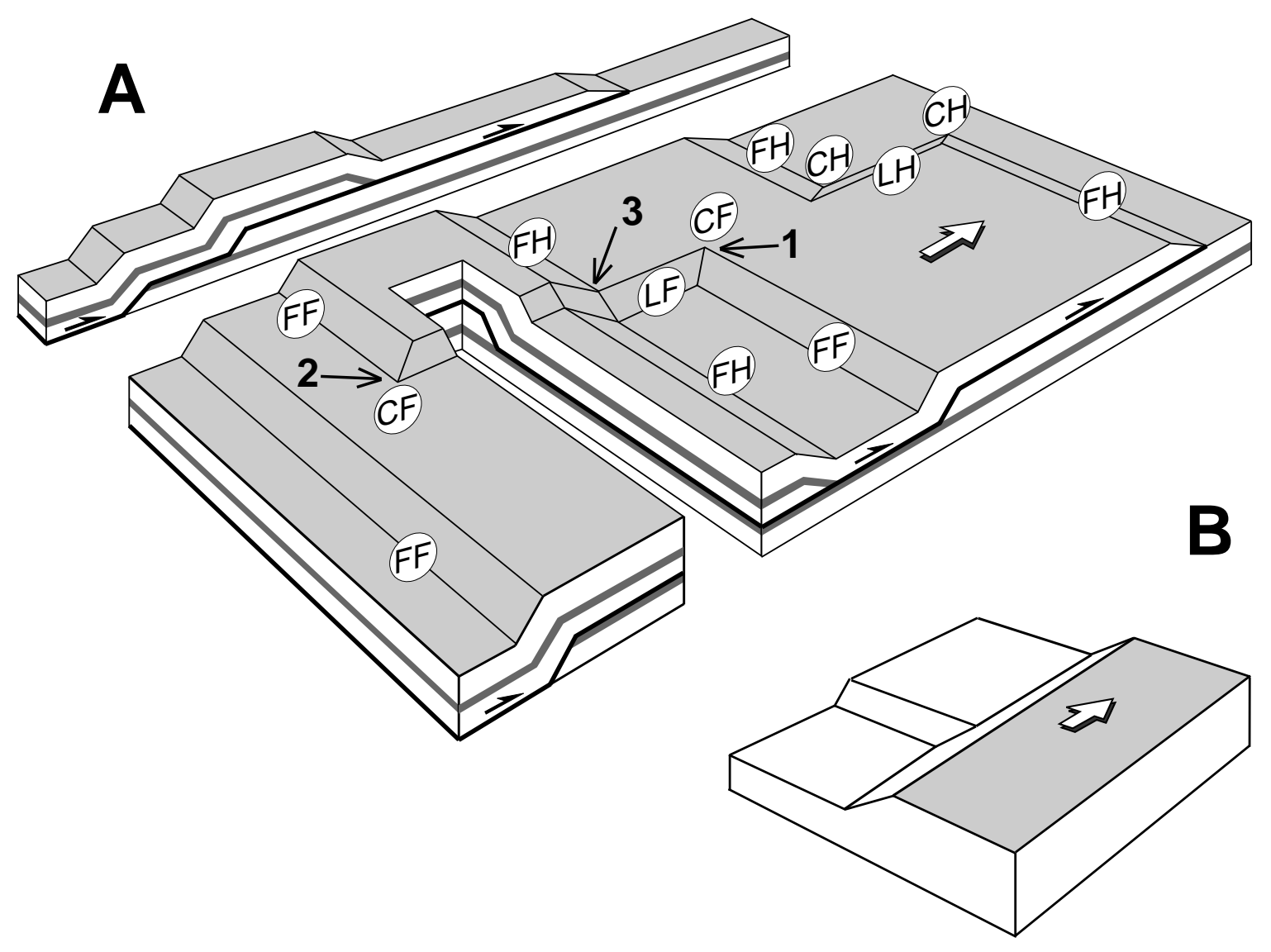

Figure 10. Alvarez-Marron 1994 

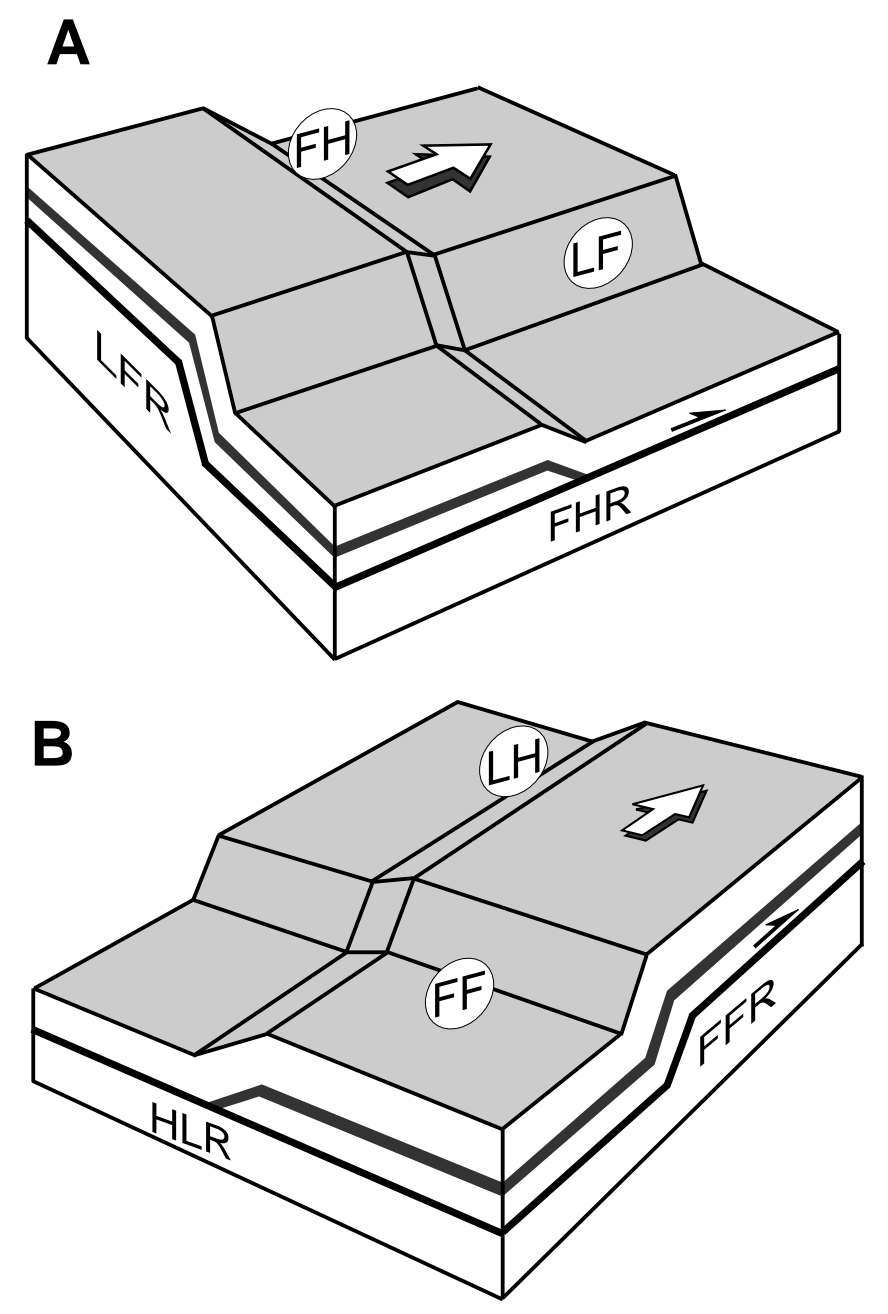

Figure 11. Alvarez-Marron 1994 